\title{
Physical Education Activity Program Survey
}

\author{
Angela Lumpkin \\ University of North Carolina \\ Marybell Avery \\ Creighton University
}

\begin{abstract}
This survey assessed the perceptions of students in the spring semester, 1984, about characteristics of and courses in the University of North Carolina's Physical Education Activities Program and obtained their suggestions for changes in the program. Frequency data and percentages were reported for each response on the 64-item questionnaire along with analysis of the data by year in college and gender. The majority of students were generally to extremely satisfied with the overall program, evaluated the quality of instruction as above average or excellent, preferred 1-hour classes twice a week for one semester in the same activity, liked having a letter or pass/fail grading option, and supported the university's two-course and swim-test requirements. Individual sports and fitness courses were the preferred offerings. Responses were consistent across years in college and gender.
\end{abstract}

Physical education activity programs at the university level merit reevaluation by administrators in order to meet students' needs, since often this is the only instructional opportunity in this discipline that students will experience. Also, restructuring and updating programs have been identified as major factors for their continued acceptance as viable parts of general education.

Hunsicker (1954) studied activity (also known as required, basic, service, and general) programs in American colleges and universities, Cordts and Shaw (1960) examined them in 1958, and Oxendine $(1961,1969,1972$; Oxendine \& Robert, 1978) conducted four separate studies over a period of 17 years. More recently, physical activity programs on the college and university level were featured in the Journal of Physical Education, Recreation and Dance in May 1982. The National Association for Sport and Physical Education sponsored a 1984 study of activity programs at 4-year colleges and universities.

Three fundamental issues regarding these programs have been discussed in the literature: required versus elected programs, grading methods, and curricular offerings. Concerning the first issue, Hunsicker (1954) surveyed approximately 100 colleges and universities and found that over $86 \%$ of the respondents required at least 1 year of activity courses for graduation; $57 \%$ of these required a second year. Also, $33 \%$ of these institu-

Request reprints from Angela Lumpkin, Dept. of Physical Education, University of North Carolina, Chapel Hill, NC 27514. 
tions mandated that students pass a swimming course or proficiency test in order to graduate. Cordts and Shaw (1960) noted a decrease to $67 \%$ in the number of schools requiring physical education, with approximately $50 \%$ of them reporting a 2-year requirement. Specific activities, most often swimming, were required by $58 \%$ of those responding.

Oxendine's surveys $(1961,1969,1972,1978)$ provided a longitudinal look at programs. He found that physical education was required for graduation by $84 \%$ of the schools in $1961,87 \%$ in $1968,74 \%$ in 1972 , and $57 \%$ in 1977 . Some $68 \%$ of the respondents in 1961 maintained a 2-year requirement, while his subsequent surveys reported $66 \%, 57 \%$, and less than $33 \%$, respectively. A swimming proficiency requirement existed in over $50 \%$ of the schools with an enrollment of 5,000 or more students in 1961 . Seventeen years later Oxendine reported that $46 \%$ of the institutions maintained this requirement.

Modifying Oxendine's instrument, Trimble and Hensley (1984) reported that the number of 4-year colleges and universities requiring physical education had stabilized at $60 \%$. A 1-year requirement remained at $41 \%$ of the institutions, while $25 \%$ of the schools retained the 2-year requirement. Although $72 \%$ reported no specific required activities, there was a tendency for smaller schools to mandate swimming.

Grading methods in physical education activity courses have remained relatively unchanged in the past 30 years. Hunsicker (1954) reported that $66 \%$ of the programs surveyed assigned letter grades, compared with $23 \%$ who use a pass/fail system of grading. Cordts and Shaw (1969) found that $74 \%$ employed letter grades and $15 \%$ used pass/fail. Only $5 \%$ of the respondents utilized a satisfactory/unsatisfactory form of evaluation, and $4 \%$ assigned numerical ratings.

Oxendine's four surveys also indicated grading variations with $74 \%, 77 \%$, and $66 \%$ of the institutions awarding letter grades in 1961,1968 , and 1972 , respectively. The pass/fail option was employed by $20 \%$ of the schools in 1968, $41 \%$ in 1972, and $31 \%$ in 1977. Some schools used both grading methods. Oxendine concluded that the smaller institutions in his sample were more likely to employ pass/fail grading. He also noted a trend toward allowing students the option of choosing a particular system of grading, although Trimble and Hensley (1984) reported that a decreased number of schools allowed this option. Of their respondents, $62 \%$ indicated a letter grading system while $24 \%$ utilized the pass/fail method. LaPoint (1982) reported that the use of letter grades was the most frequent choice in programs that gave students an option.

The literature presents some noteworthy trends in activity course offerings, particularly within the past two decades. Since the early 1960 s, team sports have declined in popularity while individual and dual sports have gained enthusiasts. Oxendine reported the emergence of recreational and fitness-oriented activities as early as 1968. O'Connor (1982) identified a philosophical emphasis on lifetime or carry-over activities in the 1970s, with tennis being the most popular. Respondents to the Trimble and Hensley study (1984) ranked these courses as most popular: (1) racquetball; (2) tennis and aerobic dance (tie); (4) jogging; (5) weight training; (6) snow skiing; (7) swimming; (8) skin and scuba diving and volleyball (tie); (10) golf, martial arts, and bowling (tie); (13) social dance; and (14) softball and soccer (tie). Individual sports led these selections with $38 \%$, while basic fitness activities contributed $17 \%$, team sports claimed $13 \%$, aquatics and dance/rhythms each comprised $11 \%$, and outdoor skills and combative activities split the remaining $10 \%$.

At the University of North Carolina at Chapel Hill, two activity program studies have been conducted by Lumpkin and Miller (1978) and by Arwe and Jacobs (1981). Rather 
than surveying administrators' opinions, both examined responses from students currently enrolled in the physical education activity program at that institution. Lumpkin and Miller attempted to determine the current status of high school physical education programs and then to ascertain the preferred curriculum offerings for physical education activities at their institution. They found that the traditional team sports of basketball, volleyball, and softball were the most often required, offered, and elected activities in the high schools in the mid-1970s.

Students preferred to enroll at the university in beginning tennis, intermediate tennis, lifesaving, water safety instructor, and racquetball. Among activities not in the curriculum at that time, students indicated interest in taking sailing, snow skiing, canoeing, backpacking, cycling, recreational sports, archery, yoga, track and field, and judo. In addition to the 1-year requirement of physical education, students indicated an interest in electing courses, with more than $25 \%$ of them desiring to enroll in one activity class every semester.

Arwe and Jacobs (1981) examined students' opinions of the existing physical education activity program and their views regarding possible changes in or additions to it. The 10 most popular activities in order of preference were tennis, racquetball, bowling, volleyball, swimming, lifesaving, self-defense, exercise and conditioning, handball, and soccer. Nontraditional offerings that students indicated they would like the program to include were similar to those noted in the earlier study-downhill skiing, sailing, horseback riding, canoeing, camping, backpacking, recreational sports, and cycling. In terms of the required versus elected question, almost $50 \%$ of the students preferred a 1-year requirement, while approximately $20 \%$ favored a totally elected program and $15 \%$ chose a one-semester requirement. If the program was entirely elective, $42 \%$ indicated they would enroll in more than two electives, $28 \%$ in the two electives, and $21 \%$ in one elective, while $9 \%$ would not enroll in a physical education activity course.

The Arwe and Jacobs study reported that 55\% of the respondents were satisfied with the letter grading system while the remainder favored a pass/fail system. Almost $60 \%$ of the students favored the swimming test requirement, while approximately the same number indicated that the swim test was of value since it ensured that students could survive in the water.

The present study examines practices and trends occurring in the 4 years since Arwe and Jacobs' research. The objectives of this research were (a) to measure students' opinions of the present activity program and (b) to survey students' interests in program changes or additions.

\section{Procedures}

Subjects $(\mathrm{N}=2,567)$ signed informed consent forms and were administered a 64-item questionnaire developed by Lumpkin and Avery to assess students' perceptions about current program characteristics, courses, and desired changes in the physical education activity program. The questionnaire was derived from a multiple response format with the response range including two to five alternatives. The subjects' responses were converted to frequencies to describe the nature of the data. These frequencies are reported as a function of gender and academic year. In addition, current activities were ranked in order of popularity as perceived by students. 


\section{Results}

Students' overall opinions of the current physical education activity program were overwhelmingly positive, as $22.87 \%$ were extremely satisfied and $67.3 \%$ were generally satisfied (see Table 1). Concerning the quality of instruction, $35.3 \%$ evaluated it as excellent, $46.5 \%$ as above average, and $16.4 \%$ as average.

Students were also questioned about their preference in scheduling, grading, and course offerings. Concerning class content, $78.3 \%$ preferred to take one activity per semester rather than two different ones $(11.7 \%)$, or one for an entire year $(8.8 \%)$. Preferred scheduling for $50.51 \%$ was the existing 1-hour classes twice a week, while the remaining responses

\section{Table 1}

\section{Descriptive data}

\begin{tabular}{lrr} 
Year in college (\%) & & \\
Freshmen & 1351 & $(52.7)$ \\
Sophomores & 593 & $(23.1)$ \\
Juniors & 288 & $(11.2)$ \\
Seniors & 299 & $(11.6)$ \\
Graduate students & 28 & $(1.1)$ \\
Gender (\%) & & \\
Females & 1472 & $(57.4)$ \\
Males & 1077 & $(42)$ \\
Experience (\%) & & \\
1st required activity & 546 & $(21.4)$ \\
2nd required activity & 1440 & $(56.3)$ \\
1st elected activity & 314 & $(12.3)$ \\
2nd elected activity & 93 & $(3.6)$ \\
More than 2nd elected & 160 & $(6.3)$ \\
$\quad$ activity & & \\
Overall opinion of program (\%) & & \\
Extremely dissatisfied & 24 & $(.9)$ \\
Generally dissatisfied & 86 & $(3.4)$ \\
No opinion & 136 & $(5.3)$ \\
Generally satisfied & 1723 & $(67.3)$ \\
Extremely satisfied & 582 & $(22.8)$ \\
\hline $\begin{array}{l}\text { Quality of instruction (\%) } \\
\text { Very poor } \\
\text { Below average }\end{array}$ & & \\
Average & 13 & $(.5)$ \\
Above average & 25 & $(.98)$ \\
Excellent & 419 & $(16.4)$ \\
Class content (\%) & 189 & $(46.5)$ \\
One activity per semester & 903 & $(35.3)$ \\
Two activities per semester & & \\
One activity per year & 1990 & $(78.3)$ \\
\hline & 298 & $(11.7)$ \\
\hline & 224 & $(8.8)$ \\
\hline
\end{tabular}


Table 1 (cont.)

Descriptive Data

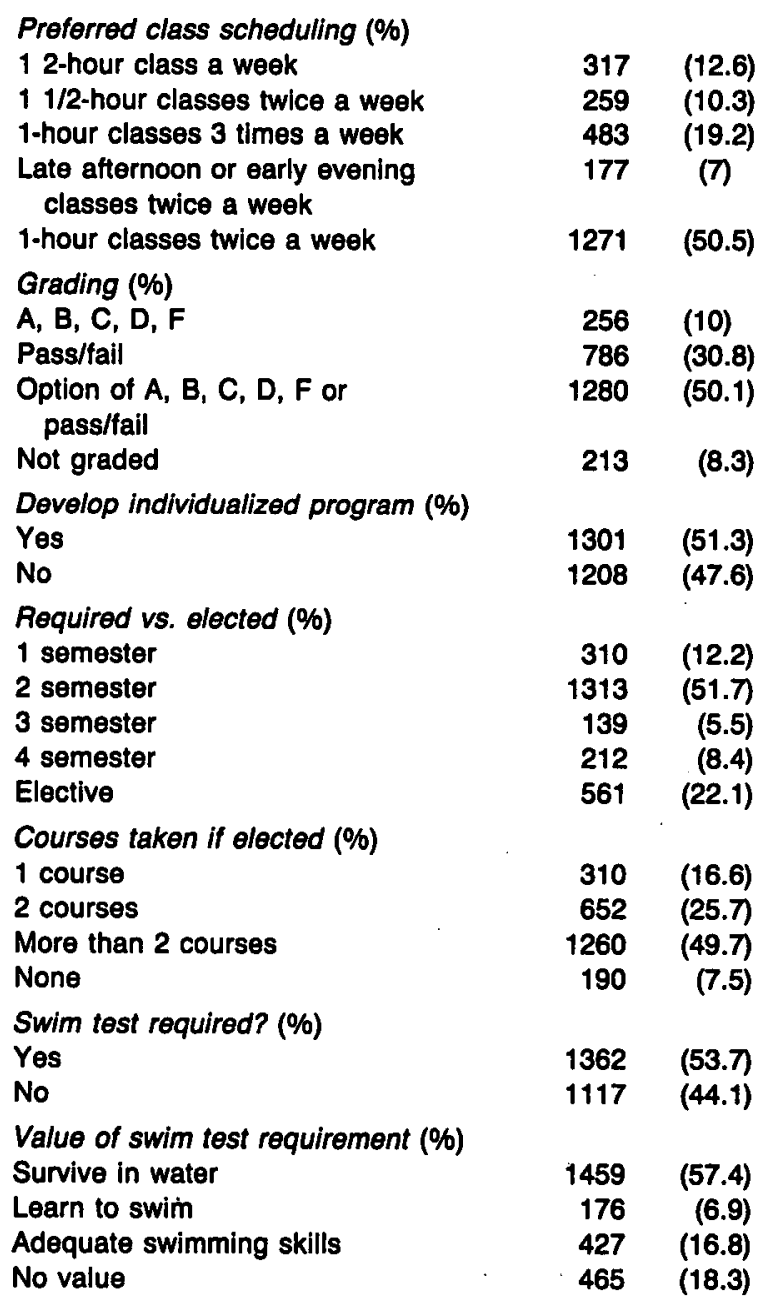

chose one 2-hour class per week, 1 1/2-hour class twice a week, 1-hour classes three times a week, and late afternoon or early evening classes twice a week for 1 hour. While $8.3 \%$ preferred having no grades in physical education activity classes, $10 \%$ selected the letter grade method, $30.8 \%$ chose the pass/fail option, and $50.1 \%$ indicated that they liked the current policy of offering the option of letter or pass/fail grading.

Responding to the question about the university's two-semester physical education activity requirement, $50.7 \%$ favored it while $12.2 \%$ preferred a one-semester, $5.5 \%$ a 
three-semester, and $8.4 \%$ a four-semester requirement. A totally elected program was desired by $22.1 \%$. If the program became totally elected, $16.6 \%$ would take one course, $25.7 \%$ would take two courses, $49.7 \%$ would take more than two courses, and $7.5 \%$ would take none. Over half (53.7\%) supported the university's required swim test. Ensuring that each student had the ability to survive in the water was the major $(57.4 \%)$ justification, with $6.9 \%$ supporting the goal that each student should learn to swim, and $16.8 \%$ noting that it ensured each student had adequate swimming skills.

Tables 2 through 8 provide data analyzed by gender and by year in college. Freshmen (19\%), sophomores (21.8\%), and juniors (28\%) took elected courses to improve their skills, while seniors (30.2\%) did so more to participate in regular physical activity (see Table 2). A steady increase in the desire to participate in regular physical activity was noted from the freshmen through graduate students' responses.

\section{Table 2}

Question 4: Why have you enrolled in this course as an elective?

$\begin{array}{lll}\begin{array}{l}\text { To learn a } \\ \text { new activity (\%) }\end{array} & \begin{array}{l}\text { To improve } \\ \text { skills (\%) }\end{array} & \begin{array}{l}\text { To participate in } \\ \text { regular physical } \\ \text { activity (\%) }\end{array} \\ F=250(17.10) & F=239(16.35) & F=277(18.95) \\ M=234(21.93) & M=285(26.71) & M=120(11.25)\end{array}$

\begin{tabular}{lrrrrrr}
\hline Freshmen & 235 & $(17.56)$ & 254 & $(18.98)$ & 136 & $(10.16)$ \\
Sophomores & 116 & $(19.76)$ & 128 & $(21.81)$ & 86 & $(14.65)$ \\
Juniors & 59 & $(20.63)$ & 80 & $(27.97)$ & 77 & $(26.92)$ \\
Seniors & 67 & $(22.48)$ & 60 & $(20.13)$ & 90 & $(30.20)$ \\
Graduate & 9 & $(32.14)$ & 6 & $(21.43)$ & 10 & $(35.71)$ \\
$\quad$ students & & & & & & \\
\hline
\end{tabular}

Males' (26.7\%) leading reason for taking elected courses was to improve skills, whereas more females (19\%) simply wanted to participate in regular physical activity. Regular exercise was the primary reason for enrollment for students in their first (41\%) or second $(37.5 \%$ ) activity class, while less than one third of each group wanted to learn a new activity or to improve skills. Those enrolled in their second elected course (34.8\%) chose skill improvement as their leading reason. Overwhelmingly, students enrolled in their first $(82.5 \%)$ or second $(82.7 \%)$ required class based their course selection on interest. Students' participation in other regular physical activity did not vary with year in college. However, males $(74.6 \%)$ were more active outside of classes than were females $(60.1 \%)$.

Opinion of the overall activity program by year in college and gender was remarkably consistent, as both groups were extremely or generally satisfied (see Table 3). More freshmen (39.8\%) and females (37.3\%) evaluated the quality of instruction as excellent (see Table 4).

Slightly more males $(69.6 \%)$ than females $(68 \%)$ indicated that they would further develop their skills and knowledge following the conclusion of their current course. Juniors 
Table 3

Question 8: What is your opinion of the current physical education activity program?

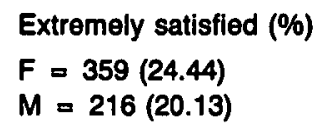

$F=359(24.44)$
$M=216(20.13)$

Generally satisfied (\%)

$F=977(66.51)$

$M=740(68.97)$

\begin{tabular}{lrrrr}
\hline Freshmen & 340 & $(25.24)$ & 882 & $(65.48)$ \\
Sophomores & 129 & $(21.83)$ & 406 & $(68.70)$ \\
Juniors & 54 & $(18.82)$ & 205 & $(71.43)$ \\
Seniors & 51 & $(17.11)$ & 205 & $(68.79)$ \\
Graduate & 8 & $(28.57)$ & 18 & $(64.29)$ \\
$\quad$ students & & & & \\
\hline
\end{tabular}

Table 4

Question 37: What best describes the quality of instruction in the activity classes you have taken?

$$
\begin{aligned}
& \text { Excellent (\%) } \\
& F=549(37.32) \\
& M=347(32.37)
\end{aligned}
$$$$
\text { Above average (\%) }
$$

$$
\begin{aligned}
& F=680(46.23) \\
& M=502(46.83)
\end{aligned}
$$

\begin{tabular}{lrrrr}
\hline Freshmen & 537 & $(39.84)$ & 597 & $\mathbf{( 4 4 . 2 9 )}$ \\
Sophomores & 193 & $(32.66)$ & 285 & $(48.22)$ \\
Juniors & 87 & $(30.31)$ & 134 & $(46.69)$ \\
Seniors & 75 & $(25.17)$ & 152 & $(51.01)$ \\
Graduate & 9 & $(32.14)$ & 16 & $(57.14)$ \\
$\quad$ students & & & & \\
\hline
\end{tabular}

(75.2\%), seniors $(72.2 \%)$, and graduate students $(89.3 \%)$ were more likely to continue to develop their skills and knowledge than were freshmen (66.9\%) and sophomores (66.3\%). All classes and both females and males preferred the twice-a-week-for-1-hour class format (see Table 5).

The two-semester requirement was supported by the majority of students-freshmen (53.5\%), sophomores (52.7\%), juniors (50.7\%), females (50.7\%), and males (53.1\%). An elected program was supported by $20.1 \%$ of the freshmen, $23.5 \%$ of the sophomores, $20.4 \%$ of the juniors, and $29.4 \%$ of the seniors. More females $(24.9 \%)$ than males $(18.3 \%)$ preferred an elected program. In the absence of a requirement, only $7.1 \%$ of the freshmen, $8 \%$ of the sophomores, $4.6 \%$ of the juniors, and $11.5 \%$ of the seniors would not enroll in one or more activity classes (see Table 6). Between 43\% (freshmen) and 66.7\% (juniors) would elect to take more than two classes. Approximately the same percentage of females (51\%) and males (47.7\%) also preferred to take more than two activity classes, while only $7 \%$ of the females and $8.2 \%$ of the males would choose to take none. 


\section{Table 5}

Question 42: If you would prefer alternative scheduling, would you be interested in:

$\begin{array}{lllll}\begin{array}{l}\text { One 2-hr } \\ \text { class } \\ (\%)\end{array} & \begin{array}{l}11 / 2 \mathrm{hrs} \\ \text { twice/wk } \\ (\%)\end{array} & \begin{array}{l}\text { One 3-hr } \\ \text { class } \\ (\%)\end{array} & \begin{array}{l}\text { Late after- } \\ \text { noon/early } \\ \text { eve. class } \\ \text { twice/wk }\end{array} & \begin{array}{l}\text { Two 1-hr } \\ \text { classes } \\ (\%)\end{array} \\ F=178 & F=108 & F=285 & F=122 & F=747 \\ (12.19) & (7.46) & \begin{array}{l}F=19.68) \\ M=137\end{array} & \begin{array}{l}M=150 \\ (8.43)\end{array} & \begin{array}{l}M=193 \\ (51.59)\end{array} \\ \begin{array}{l}M=52 \\ (12.83)\end{array} & (14.26) & (18.35) & (4.94) & \begin{array}{l}M=520 \\ (49.43)\end{array}\end{array}$

\begin{tabular}{lrlrlrlllll}
\hline Freshmen & 172 & $(13.01)$ & 128 & $(9.68)$ & 230 & $(17.40)$ & 195 & $(7.19)$ & 694 & $(52.5)$ \\
Sophomores & 76 & $(12.99)$ & 54 & $(9.23)$ & 110 & $(18.8)$ & 38 & $(6.5)$ & 305 & $(52.14)$ \\
Juniors & 27 & $(9.61)$ & 41 & $(14.59)$ & 56 & $(19.93)$ & 19 & $(6.76)$ & 136 & $(48.4)$ \\
Seniors & 36 & $(12.2)$ & 30 & $(10.17)$ & 78 & $(26.44)$ & 24 & $(8.14)$ & 124 & $(42.03)$ \\
Graduate & 4 & $(14.29)$ & 6 & $(21.43)$ & 8 & $(28.57)$ & - & - & 10 & $(35.71)$ \\
$\quad$ students & & & & & & & & & &
\end{tabular}

Table 6

Question 46: If the program became totally elective, would you take:

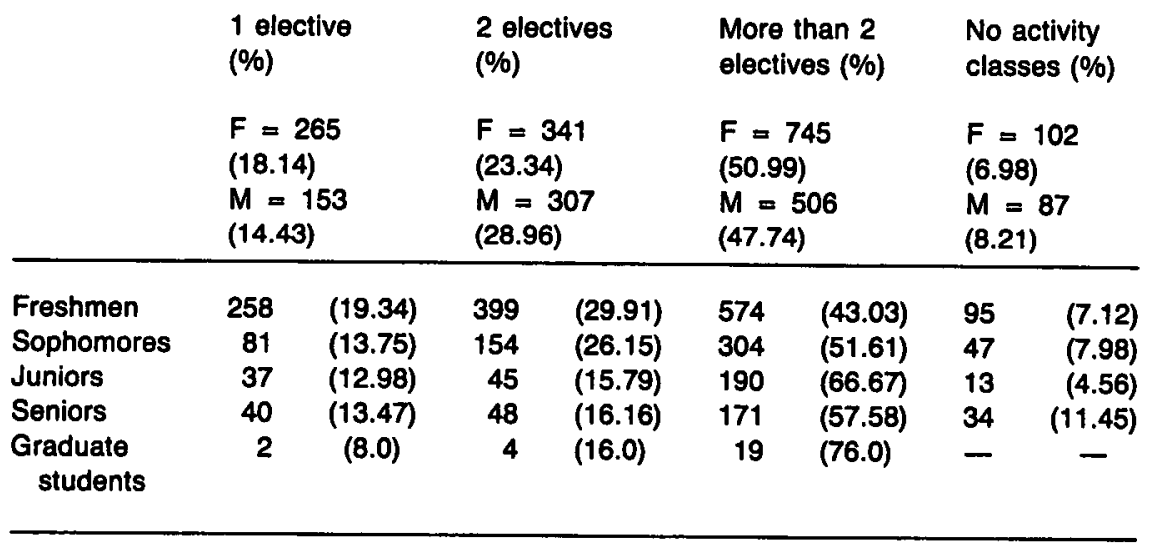

Over half of the freshmen (51.34\%), sophomores (51.2\%), juniors $(51.2 \%)$, and women $(51 \%)$ preferred the option of letter or pass/fail grading, as did those taking elected courses. Ten percent or less of all groups supported nongraded classes (see Table 7). Approximately half of the classes and students of both genders expressed an interest in developing a personal activity program (see Table 8). Of the 28 different activities offered in the program, the 10 that students indicated the greatest interest in taking were tennis, 
Table 7

Question 47: How would you prefer physical education activity classes to be graded?

\begin{tabular}{|c|c|c|c|c|c|c|c|c|}
\hline & \multicolumn{2}{|c|}{$\begin{array}{l}\text { A, B, C, D, F } \\
(\%)\end{array}$} & \multicolumn{2}{|c|}{$\begin{array}{l}\text { Pass/fail } \\
(\%)\end{array}$} & \multicolumn{2}{|c|}{$\begin{array}{l}\text { Option of grades } \\
\text { or pass/fail (\%) }\end{array}$} & \multicolumn{2}{|c|}{$\begin{array}{l}\text { Not graded } \\
(\%)\end{array}$} \\
\hline & \multicolumn{2}{|c|}{$\begin{array}{l}F=112 \\
(7.64) \\
M=143 \\
(13.36)\end{array}$} & \multicolumn{2}{|c|}{$\begin{array}{l}F=470 \\
(32.06) \\
M=309 \\
(28.88)\end{array}$} & \multicolumn{2}{|c|}{$\begin{array}{l}F=747 \\
(50.95) \\
M=529 \\
(49.44)\end{array}$} & \multicolumn{2}{|c|}{$\begin{array}{l}F=129 \\
(8.80) \\
M=81 \\
(7.57)\end{array}$} \\
\hline Freshmen & 156 & (11.62) & 385 & (28.69) & 689 & (51.34) & 104 & (7.75) \\
\hline Sophomores & 55 & (9.29) & 176 & (29.73) & 303 & (51.18) & 52 & (8.78) \\
\hline Juniors & 24 & (8.36) & 97 & (33.80) & 147 & (51.22) & 19 & (6.62) \\
\hline Seniors & 19 & (6.35) & 119 & (39.80) & 129 & (43.14) & 30 & (10.03) \\
\hline $\begin{array}{l}\text { Graduate } \\
\text { students }\end{array}$ & 1 & $(4.0)$ & 6 & $(24.0)$ & 10 & $(40.0)$ & 7 & $(28.0)$ \\
\hline
\end{tabular}

Table 8

Question 61: Would you be interested in developing a personal activity program in lieu of one semester of the present physical education requirement?

$\begin{array}{ll}\text { Yes (\%) } & \text { No }(\%) \\ F=754(51.79) & F=694(47.66) \\ M=539(50.66) & M=507(47.65)\end{array}$

\begin{tabular}{lrlrl}
\hline Freshmen & 689 & $(51.53)$ & 633 & $\mathbf{( 4 7 . 3 4 )}$ \\
Sophomores & 302 & $(51.45)$ & 281 & $(47.87)$ \\
Juniors & 146 & $(51.23)$ & 135 & $(47.37)$ \\
Seniors & 154 & $(51.85)$ & 138 & $(46.46)$ \\
Graduate & 9 & $(36.0)$ & 16 & $(64.0)$ \\
$\quad$ students & & & & \\
\hline
\end{tabular}

racquetball, downhill skiing, weight training, swimming, bowling, aerobic dance, exercise and conditioning, life-saving, and golf, respectively (see Table 9).

When each course, such as beginning tennis and intermediate tennis, was measured individually rather than as an activity, the top ranked offerings (all beginners' courses) were racquetball, scuba diving, karate, downhill skiing, weight training, bowling, fencing, golf, tennis, and handball. Thirteen activities were listed for students to check whether they would elect to enroll if offered. Their rank order with percentages of positive responses was sailing $(72.9 \%)$, horseback riding $(67.9 \%)$, ice skating $(63.2 \%)$, canoeing (53.9\%), cross-country skiing $(53.7 \%)$, cycling $(47 \%)$, camping $(41.8 \%)$, recreational sports $(39.4 \%)$, backpacking $(38.5 \%)$, judo $(30.6 \%)$, crew $(29.2 \%)$, track and field (24.7\%), and yoga (22.9\%). 


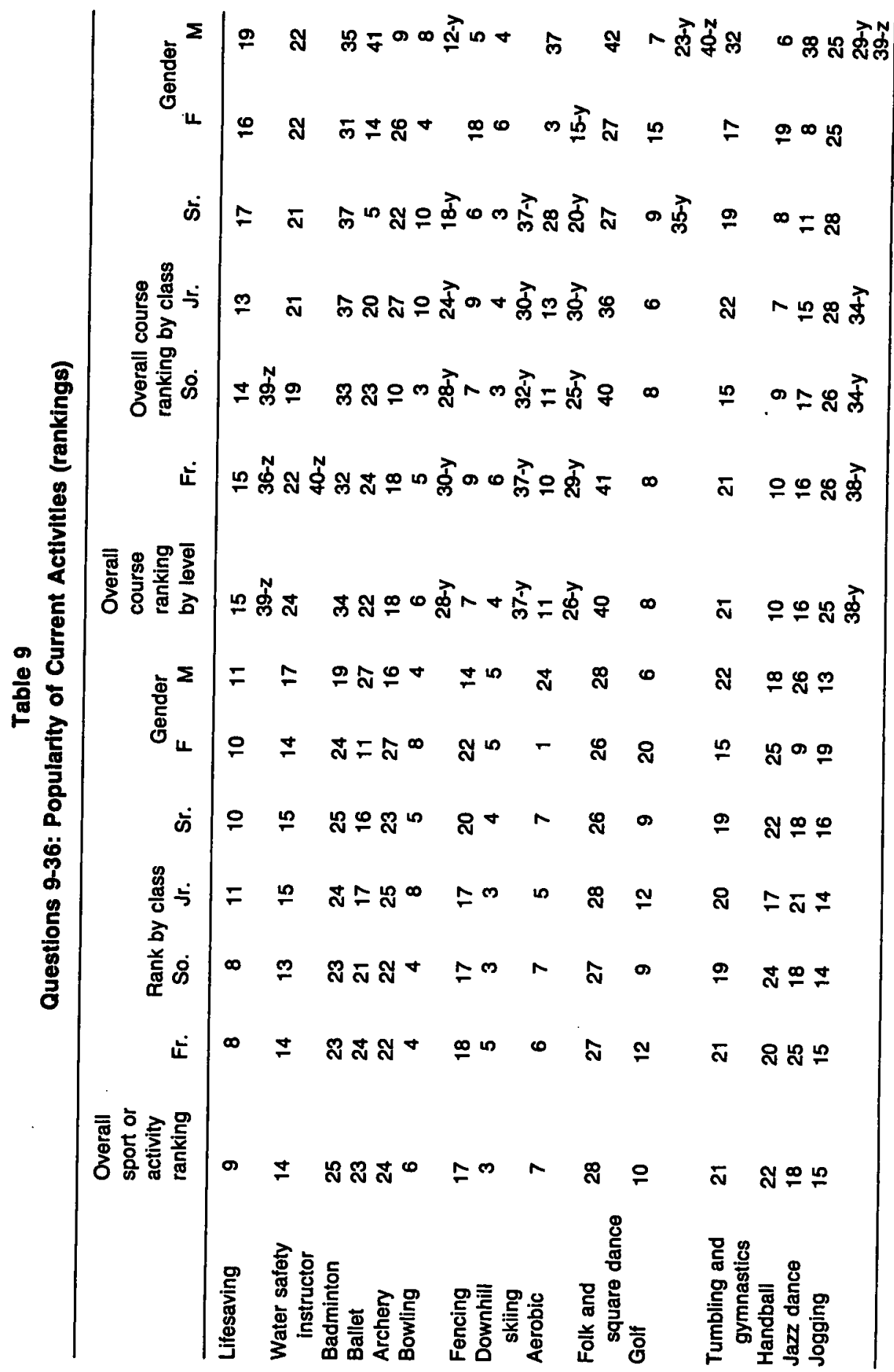




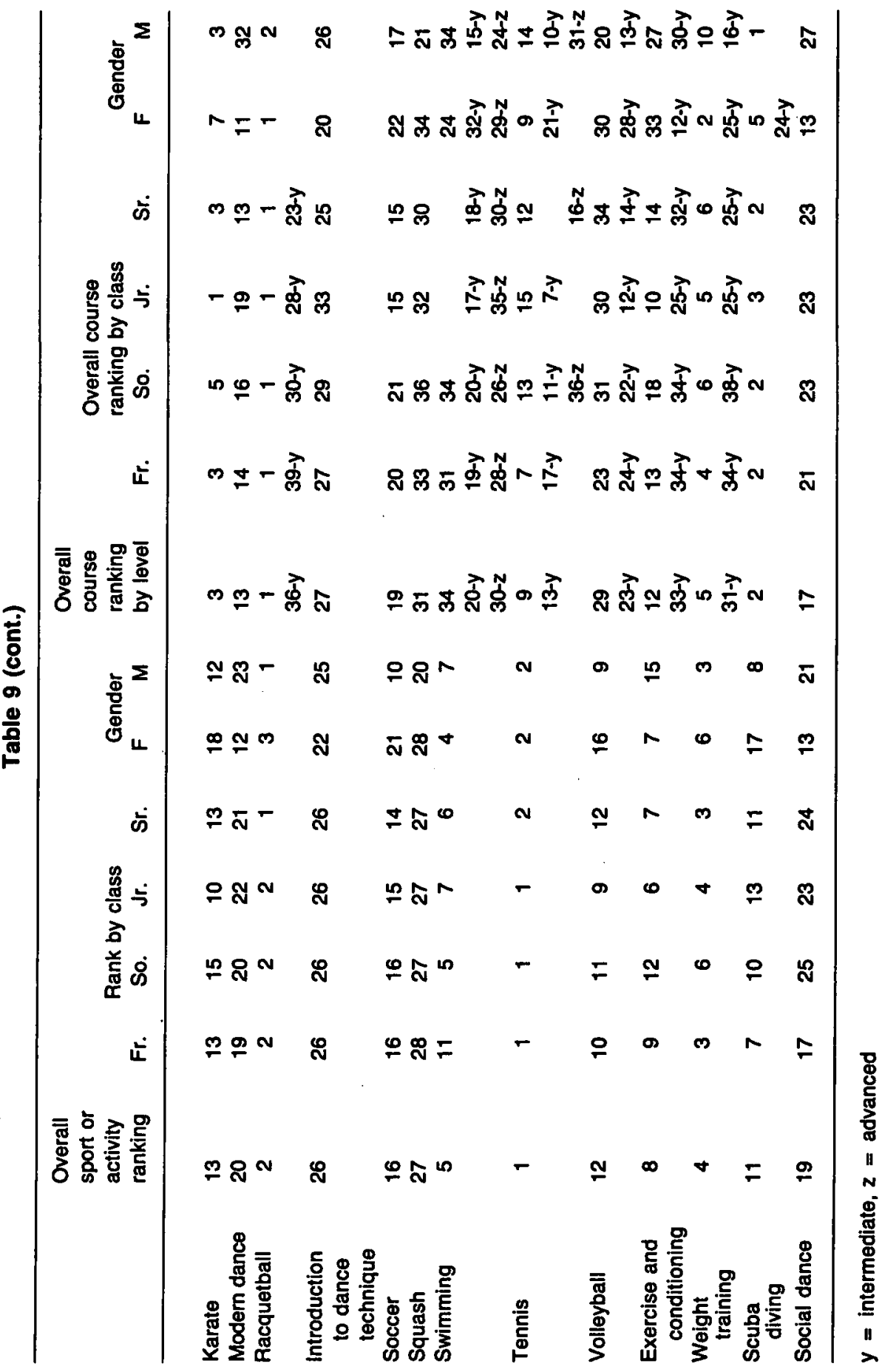




\section{Discussion}

The students' overall opinions of the current physical education activity program were most favorable. Over two-thirds of the respondents indicated they were generally satisfied, while more than one-fifth said they were extremely satisfied with the current program. The most popular activities in the program have changed only slightly since the Arwe and Jacobs study 4 years earlier. Six of those activities previously rated in the top 10 were given the same distinction in the previous study. No team sports appeared in the list of the 10 most popular activities. The list was dominated by individual sports such as tennis, racquetball, downhill skiing, bowling, golf, and fitness-oriented activities such as weight training, swimming, aerobics, and exercise and conditioning. It would appear that the trend toward activities of a recreational and fitness nature noted by Oxendine in 1968 continued to increase through 1984, supporting the findings of Trimble and Hensley (1984).

In terms of the required versus elected program, student opinion has not changed significantly in the past 4 years. Slightly more than half of the respondents favored the current two-semester requirement, a small increase over the previous study's results. There was a slight increase in the number who favored a totally elected program, from $20 \%$ in 1980 to $22 \%$ in 1984 . The popularity of the program was verified by the almost $50 \%$ of the students who indicated they would take more than two activity courses even if not required. This figure compares favorably with the response reported in 1980.

\section{Conclusion}

It is important to determine that the majority. of students are satisfied with the existing physical education activities program. However, changes in interests in preferred offerings indicate that administrators cannot afford to rest on their laurels. The program must be examined regularly in order to be sure it is relevant to students' needs and interests, as well as to expand offerings. Activity courses offer many students an introduction to physical education, provide a positive learning environment for fitness and skill development, and thus comprise a valuable part of students' total educational experience. While the findings of this study may not be generalizable to other colleges and universities, administrators may find that these results substantiate their personal assessments of national trends as they affect local activity programs. Also, this study may encourage administrators to evaluate students' perceptions of the existing program structure and students' interests in new courses in their institution.

\section{References}

Arwe, K.E., \& Jacobs, K. (1981). The required activity program: A student evaluation at the University of North Carolina at Chapel Hill. The North Carolina Journal, 17(1), 9-15.

Cordts, H.J., \& Shaw, J.H. (1960). Status of the physical education required or instructional programs in four-year colleges and universities. Research Quarterly, 31, 409-419.

Hunsicker, P.A. (1954). A survey of service physical education programs in American colleges and universities. Fifty-Seventh Annual Proceedings of the College Physical Education Association, pp. 29-30. 
LaPoint, J.D. (1982). Current status. Joumal of Physical Education, Recreation and Dance, 53(5), 49-51.

Lumpkin, A., \& Miller, B. (1978). Physical education activities survey. The North Carolina Joumal, 14(1), 24-34.

O'Connor, J.S. (1982). Innovations. Journal of Physical Education, Recreation and Dance, 53(5), 52-55.

Oxendine, J.B. (1961). The service program in 1960-1961. Joumal of Health, Physical Education and Recreation, 32(7), 37-38.

Oxendine, J.B. (1969). Status of required physical education programs in colleges and universities. Journal of Health, Physical Education and Recreation, 40(1), 32-35.

Oxendine, J.B. (1972). Status of general instruction programs of physical education in four-year colleges and universities: 1971-72. Joumal of Health, Physical Education and Recreation, 43(3), 26-28.

Oxendine, J.B., \& Robert, J.E. (1978). The general instruction program in physical education at four-year colleges and universities: 1977. Journal of Physical Education and Recreation, 49(1), 21-23.

Trimble, R.T., \& Hensley, L.D. (1984). The general instruction program in physical education at four-year colleges and universities: 1982. Joumal of Physical Education, Recreation and Dance, 55(5), 82-89. 
Copyright of Journal of Teaching in Physical Education is the property of Human Kinetics Publishers. Inc. and its content may not be copied or emailed to multiple sites or posted to a listserv without the copyright holder's express written permission. However, users may print, download, or email articles for individual use. 